\title{
報 告 II
}

\section{Cefmetazole の吸収，排泄，分布，代謝について}

\author{
岐皁大学泌尿器科学教室
}

河田幸道

\section{Key words: Cefmetazole, Metabolism, Blood level}

\section{I. はじめに}

Cefmetazole の吸収，排泄，分布，代謝などに 関して, Table 1 に示した全国32の研究機関より 寄せら机た成績を集計した。貴重な資料を御提供 頂いた各機関に深謝する。

\section{II. 成 績}

1. 体液内濃度の測定方法

体液内濃度の測定方法は各研究機関により若干
異り，Table 2 に示したようにいくつかの方法が 行われているが，M. luteus を検定菌とした薄層 カップ法により測定したものが多く，また血中濃 度の測定の際の標準液系列の希釈には，七ト血清 を用いたものが多かつた。

まず検定菌に関しては，Fig. 1のようにB. subtilis を用いた場合よりも，M. luteus を用い た場合の流うが感度はすぐれているが，測定值自

Table 1 List of Cooperated Institute

Department of Microbiology, Kyoto College of Pharmacy

Second Department of Internal Medicine, Hokkaido University, School of Medicine

Second Department of Internal Medicine, Niigata University, School of Medicine

Internal Medicine, Suibarago Hospital

Department of Internal Medicine, Shinrakuen Hospital

The Department of Internal Medicine, The Institute of Medical Science, The University of Tokyo

Second Department of Internal Medicine, The Jikei University, School of Medicine

Department of Internal Medicine, Tokyo Women's Medical College

Department of Internal Medicine, Tokyo Kyosai Hospital

Department of Internal Medicine, Kawasaki Municipal Kawasaki Hospital

Department of Internal Medicine, Nagoya City University, School of Medicine

First Department of Internal Medicine, Kansai Medical University

Division of Respiratory Diseases of Internal Medicine, Kawasaki Medical School

Second Department of Internal Medicine, Nagasaki University, School of Medicine

Department of Internal Medicine, Institute for Toropical Medicine, Nagasaki University

First Department of Internal Medicine, Kumamoto
University, School of Medicine

Department of Urology, Sapporo Medical College

Department of Urology, Faculty of Medicine, The University of Tokyo

Department of Urology, Tokai University, School of Medicine

Department of Urology, Kanazawa University, School of Medicine

Department of Urology, Gifu University, School of Medicine

Department of Urology, Kobe University, School of Medicine

Department of Urology, Okayama University, Medical School

Department of Urology, Kagoshima University, School of Medicine

Third Department of Surgery, Nihon University, School of Medicine

Department of Surgery, Keio University, School of Medicine

First Department of Surgery, Nagoya City University, School of Medicine

Second Department of Surgery, Osaka City University, Medical School

First Department of Surgery, Faculty of Medicine, Kyushu University

First Department of Surgery, Fukuoka University, School of Medicine

Department of Obstetrics and Gynecology, Kawasaki Medical School

Central Research Laboratories, Sankyo Co., Ltd. 
Table 2 Bioassay Method for Cefmetazole

\begin{tabular}{|c|c|c|c|c|}
\hline Test organism & \multicolumn{2}{|c|}{ M. luteus ATCC 9341} & \multicolumn{2}{|c|}{ B. subtilis ATCC 6633} \\
\hline Method & Cup plate & Disc plate & Cup plate & Disc plate \\
\hline Medium & \multicolumn{2}{|c|}{ Heart Infusion Agar } & \multicolumn{2}{|c|}{ Nutrient Agar } \\
\hline Diluent & \multicolumn{4}{|c|}{$1 \%$ Phosphate Buffer (pH 6.0) } \\
\hline Sample & Serum & Serum & Serum & Serum \\
\hline \multirow[t]{2}{*}{$\begin{array}{l}\text { Standard } \\
\text { solution }\end{array}$} & $\begin{array}{l}\text { Serum } \\
\text { Moni-Trol I } \\
\text { Consera }\end{array}$ & $\begin{array}{l}\text { Serum } \\
\text { Moni-Trol I } \\
\text { Coosera }\end{array}$ & $\begin{array}{l}\text { Serum } \\
\text { Moni-Trol I } \\
\text { Consera }\end{array}$ & $\begin{array}{l}\text { Serum } \\
\text { Moni-Trol I } \\
\text { Consera }\end{array}$ \\
\hline & Buffer & Buffer & Buffer & Buffer \\
\hline Detective range $(\mu \mathrm{g} / \mathrm{ml})$ & $0.6 \sim 200$ & $1 \sim 200$ & $6 \sim 200$ & $12 \sim 200$ \\
\hline
\end{tabular}

Fig. 1 Standard Curve of Cefmetazole

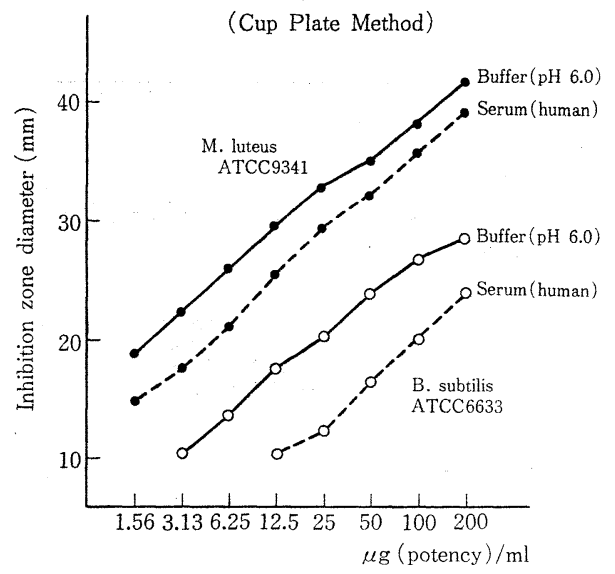

体は Fig. 2 のように，両者の成績はきわめてよ く相関しており，またカップ法とディスク法の測

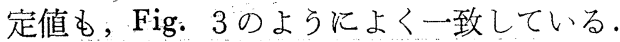

しかし標準液系列の希釈に関しては， bufferを 用いた場合，その $\mathrm{pH}$ による影響は Fig. 4 のよ うに匡とんど見られないが， buffer と血清，特よ び血清の種類によつては，Fig. 5 のように若干 影響されている。

これらのことから血中濃度の集計に際しては， ヒト血清希釈の成績と buffer 希釈の成績とを別 個に集計することとし，また必要に応じて希釈に 用いた血清の種類を記載することとした。

2. 血中濃度
Fig. 2 Correlation between blood level values assayed by $M$. luteus and B. subtilis

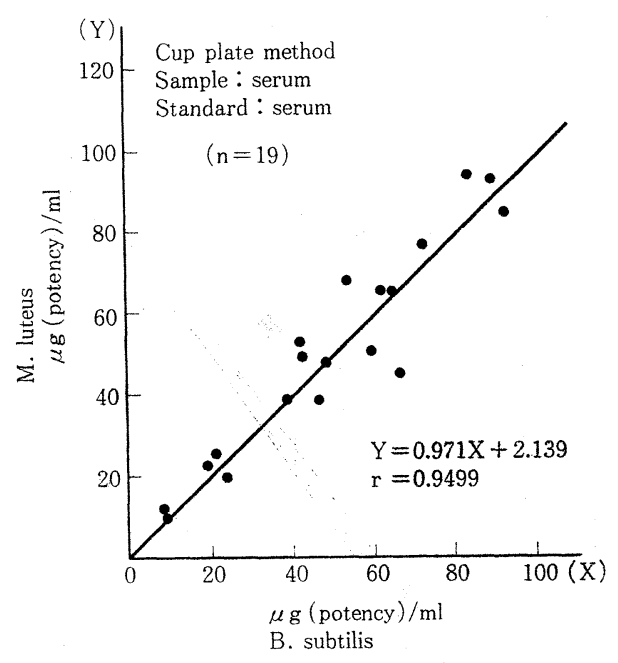

まず，健康成人に括ける血中濃度であるが，筋 注の場合は Fig. 6 のように，500mg 1 回筋注 では peak は30分後に認められ, 平均 $32.5 \mu \mathrm{g} / \mathrm{ml}$, 以後漸減して 6 時間後には平均 $2.8 \mu \mathrm{g} / \mathrm{ml}$ となり, half life は1.43時間であるが, buffer 希釈での測 定值はこれより低い傾向を示している。また 250 mg 1 回筋注でも, peak 130 分後に認められ, 平均 $20.5 \mu \mathrm{g} / \mathrm{ml} ， 6$ 時間後には平均 $0.4 \mu \mathrm{g} / \mathrm{ml}$ とな り, half life は1.19時間となつている。

つぎに one shot 静注の場合についてみると, 
Fig. 3 Correlation between Cup Plate Method and Disc Plate Method

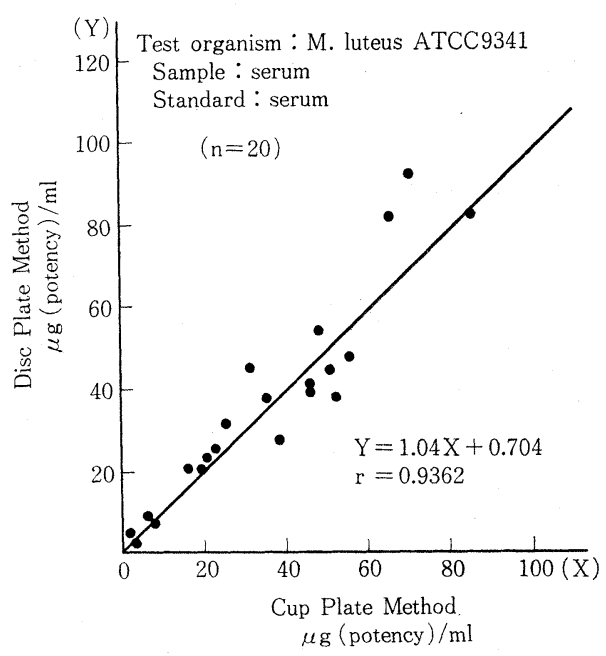

Fig. 4 Influence of Buffer pH

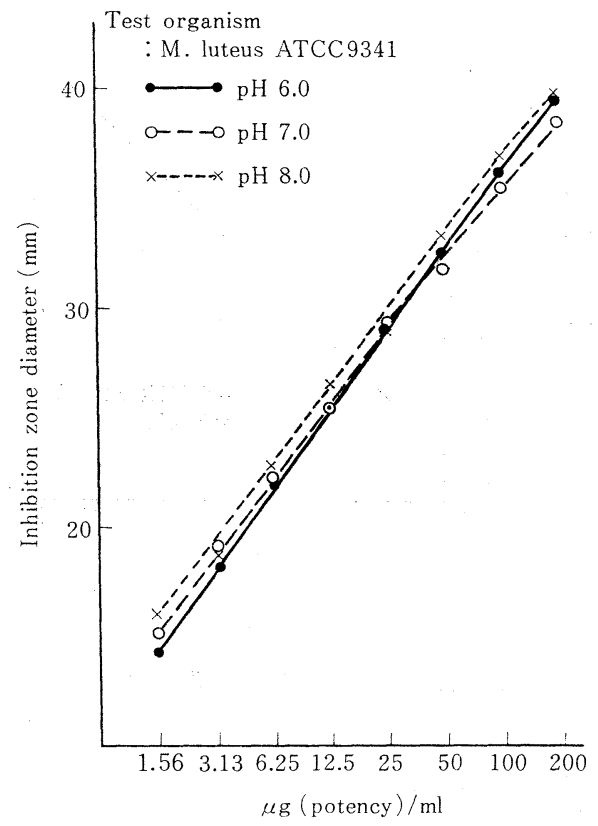

Fig. 7 のように 1 回 $2 \mathrm{~g}, 1 \mathrm{~g}, 500 \mathrm{mg}$ 投与のいず れに拈いても静注直後に peak が認められ，投与 量に応じた高い血中濃度が得られているが，その 後の血中からの消失は比較的はやく, half life は 汪ほ 1 時間前後となつている。

点滴静注の場合は Fig. 8 のように, いずれも
Fig. 5 Influence of a kind of Diluent

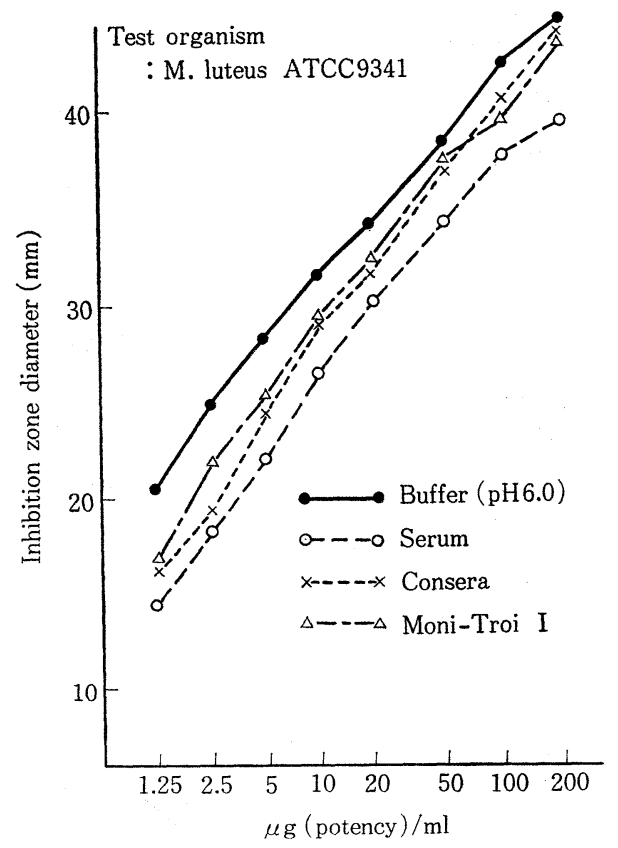

Fig. 6 Serum Level of Cefmetazole 1) Intramuscular Injection

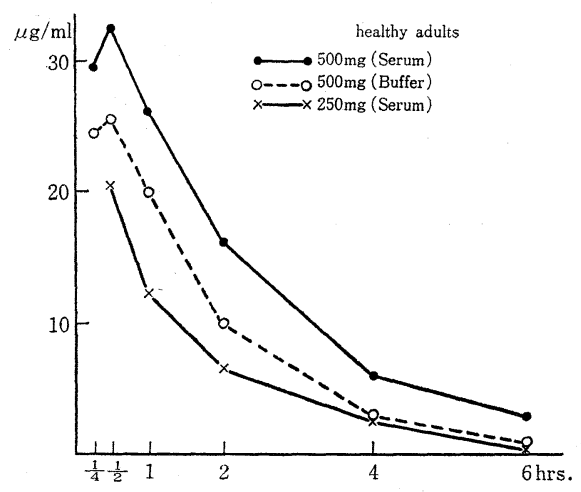

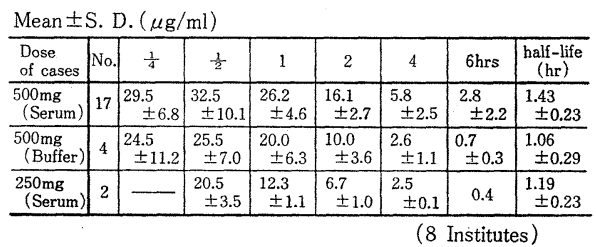

点滴終了時に peak が認められ， $4 \mathrm{~g}$ 投与で 160 , $2 \mathrm{~g}$ で109, $1 \mathrm{~g}$ で76, 500mg で $41 \mu \mathrm{g} / \mathrm{ml}$ となり, half life は匡ぼ1.2時間前後となつている。 
Fig. 7 Serum Level of Cefmetazole 2) Intravenous Injection

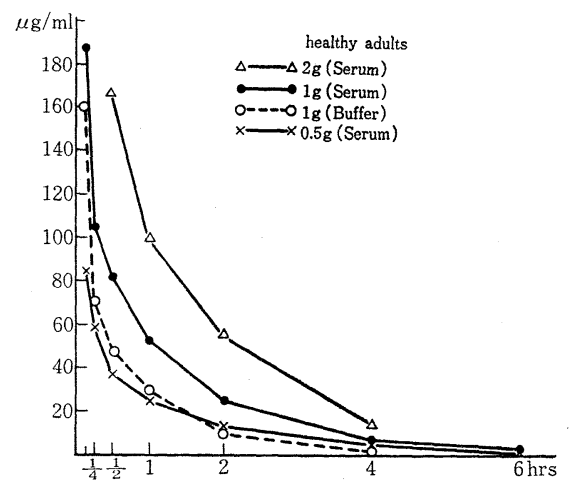

Mean \pm S. D. $(\mu \mathrm{g} / \mathrm{ml})$

\begin{tabular}{|c|c|c|c|c|c|c|c|c|c|}
\hline $\begin{array}{c}\begin{array}{c}\text { Dose } \\
\text { of cases }\end{array} \\
\end{array}$ & No. & $\frac{1}{6}$ & $\frac{1}{4}$ & $\frac{-1}{2}$ & 1 & 2 & 4 & $6 \mathrm{hrs}$ & \begin{tabular}{|c}
$\begin{array}{c}\text { half-life } \\
(\mathrm{hr})\end{array}$ \\
\end{tabular} \\
\hline $2 \mathrm{~g}($ Serum $)$ & 4 & - & - & \begin{tabular}{|l|}
167 \\
\pm 20.2 \\
\end{tabular} & \begin{tabular}{|l|}
99.8 \\
\pm 14.5 \\
\end{tabular} & \begin{tabular}{|l|}
55.6 \\
\pm 5.1 \\
\end{tabular} & $\begin{array}{c}13.5 \\
\pm 2.5 \\
\end{array}$ & - & $\begin{array}{c}0.99 \\
\pm 0.06\end{array}$ \\
\hline $1 \mathrm{~g}($ Serum $)$ & 19 & \begin{tabular}{|l|}
188 \\
\pm 30.2
\end{tabular} & \begin{tabular}{|l|}
105.5 \\
\pm 19.5 \\
\end{tabular} & $\begin{array}{l}82.1 \\
\pm 15.6 \\
\end{array}$ & \begin{tabular}{|l|}
52.6 \\
\pm 11.2
\end{tabular} & \begin{tabular}{|l|}
24.8 \\
\pm 9.1
\end{tabular} & $\begin{array}{c}6.3 \\
\pm 2.5\end{array}$ & $\begin{array}{l}1.9 \\
\pm 0.7\end{array}$ & $\begin{array}{l}0.99 \\
\pm 0.16\end{array}$ \\
\hline $1 \mathrm{~g}$ (Buffer) & 7 & 161 & \begin{tabular}{|l|}
70.5 \\
\pm 12.9
\end{tabular} & $\mid$\begin{tabular}{|l|}
47.6 \\
\pm 10.3
\end{tabular} & $\left|\begin{array}{c}29.6 \\
\pm 11.4\end{array}\right|$ & $\begin{array}{c}9.1 \\
\pm 3.5\end{array}$ & 1.0 & trace & $\begin{array}{l}0.78 \\
\pm 0.20\end{array}$ \\
\hline$g($ Serum $)$ & 5 & $\begin{array}{c}85.3 \\
\pm 6.1 \\
\end{array}$ & $\begin{array}{c}58.0 \\
\pm 6.7 \\
\end{array}$ & $\begin{array}{c}37.1 \\
\pm 5.8 \\
\end{array}$ & $\begin{array}{c}25.4 \\
\pm 6.1 \\
\end{array}$ & \begin{tabular}{c|}
12.6 \\
\pm 4.1 \\
\end{tabular} & \begin{tabular}{|l|}
5.2 \\
\pm 1.7 \\
\end{tabular} & 0.9 & $\begin{array}{c}1.16 \\
\pm 0.15 \\
\end{array}$ \\
\hline
\end{tabular}

Fig. 8 Serum Level of Cefmetazole 3) Drip Infusion

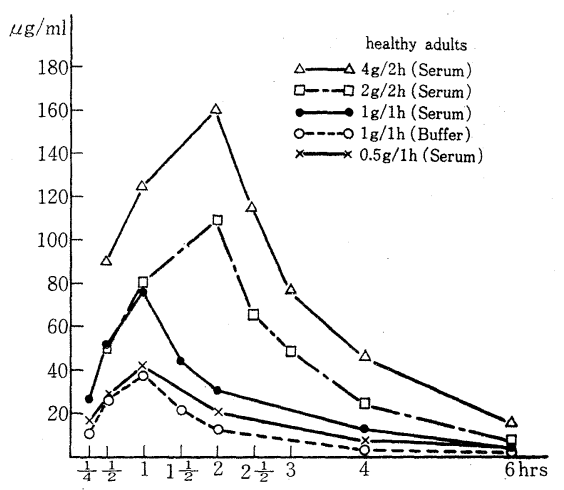

Mean \pm S. D. $(\mu \mathrm{g} / \mathrm{ml})$

\begin{tabular}{|c|c|c|c|c|c|c|c|c|c|c|c|}
\hline $\begin{array}{l}\text { Dose } \\
\text { of cases }\end{array}$ & No. & $\frac{1}{4}$ & $\frac{1}{2}$ & 1 & $1 \frac{1}{2}$ & 2 & $2 \frac{1}{2}$ & 3 & 4 & $6 \mathrm{hrs}$ & $\begin{array}{c}\text { half-life } \\
(\mathrm{hr})\end{array}$ \\
\hline $4 \mathrm{~g}$ (Serum) & 4 & - & $\begin{array}{l}89.8 \\
\pm 17.2\end{array}$ & \begin{tabular}{|l|}
124 \\
24.5 \\
\end{tabular} & & \begin{tabular}{|l|}
160 \\
\pm 37.0
\end{tabular} & \begin{tabular}{|l|}
115 \\
\pm 28.3
\end{tabular} & \begin{tabular}{|l|}
76.3 \\
\pm 17.6 \\
\end{tabular} & \begin{tabular}{|l|}
45.5 \\
\pm 10.2 \\
\end{tabular} & \begin{tabular}{|c|}
14.8 \\
\pm 4.6
\end{tabular} & $\begin{array}{c}1.22 \\
\pm 0.28\end{array}$ \\
\hline $2 \mathrm{~g}$ (Serum) & 10 & - & $\begin{array}{c}50.0 \\
\pm 6.1\end{array}$ & $\mid \begin{array}{l}79.7 \\
\pm 14.3 \\
\end{array}$ & & $\begin{array}{l}109 \\
\pm 21.1\end{array}$ & $\begin{array}{l}65.4 \\
\pm 20.0 \\
\end{array}$ & $\begin{array}{l}48.4 \\
\pm 18.8\end{array}$ & $\begin{array}{c}24.3 \\
\pm 7.0 \\
\end{array}$ & $\begin{array}{l}6.0 \\
\pm 1.6\end{array}$ & $\begin{array}{l}1.16 \\
\pm 0.10\end{array}$ \\
\hline $1 \mathrm{~g}$ (Serum) & 14 & $\begin{array}{l}26.3 \\
\pm 12.0\end{array}$ & $\begin{array}{l}51.9 \\
\pm 11.1\end{array}$ & \begin{tabular}{|l|}
76.2 \\
\pm 14.0
\end{tabular} & \begin{tabular}{|l|}
43.8 \\
\pm 14.2
\end{tabular} & \begin{tabular}{|l|}
30.1 \\
\pm 13.2 \\
\end{tabular} & - & - & \begin{tabular}{l|}
12.3 \\
\pm 11.6
\end{tabular} & \begin{tabular}{|l|}
.7 \\
\pm 2.2 \\
\end{tabular} & $\begin{array}{c}1.09 \\
\pm 0.22\end{array}$ \\
\hline 1g (Buffer) & 8 & $\begin{array}{c}11.0 \\
\pm 4.0\end{array}$ & $\begin{array}{c}25.5 \\
\pm 4.1\end{array}$ & $\begin{array}{c}37.7 \\
\pm 5.5\end{array}$ & $\begin{array}{c}21.6 \\
\pm 5.2\end{array}$ & $\begin{array}{l}12.1 \\
\pm 2.4\end{array}$ & - & 3 & $\mid \begin{array}{l}3.4 \\
\pm 1.4\end{array}$ & $\mid \begin{array}{l}1.2 \\
\pm 0.7\end{array}$ & $\begin{array}{l}1.13 \\
\pm 0.29\end{array}$ \\
\hline $0.5 \mathrm{~g}($ Serum $)$ & 3 & $\begin{array}{l}16.8 \\
\pm 3.5 \\
\end{array}$ & $\begin{array}{l}26.5 \\
\pm 2.6 \\
\end{array}$ & \begin{tabular}{|l|}
41.1 \\
\pm 1.8 \\
\end{tabular} & - & $\begin{array}{c}19.3 \\
\pm 0.8 \\
\end{array}$ & - & - & \begin{tabular}{|l|}
6.4 \\
\pm 1.2 \\
\end{tabular} & \begin{tabular}{|l|}
3.0 \\
\pm 0.4
\end{tabular} & $\begin{array}{c}1.35 \\
\pm 0.06\end{array}$ \\
\hline
\end{tabular}

Fig. 9 Dose Response in Serum Levels 1) Intramuscular Injection

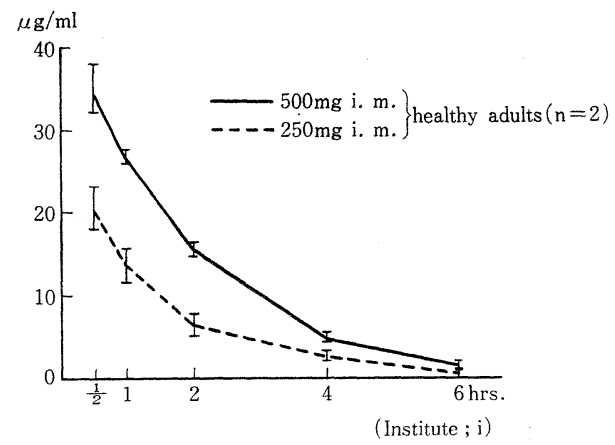

Fig. 10 Dose Response in Serum Levels 2) Intravenous Injection

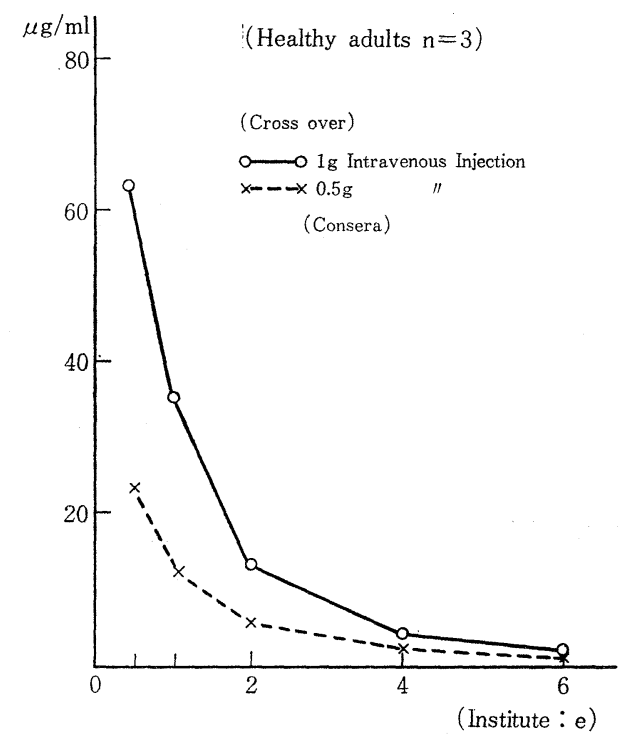

Fig. 11 Dose Response in Serum Levels 3) Drip Infusion

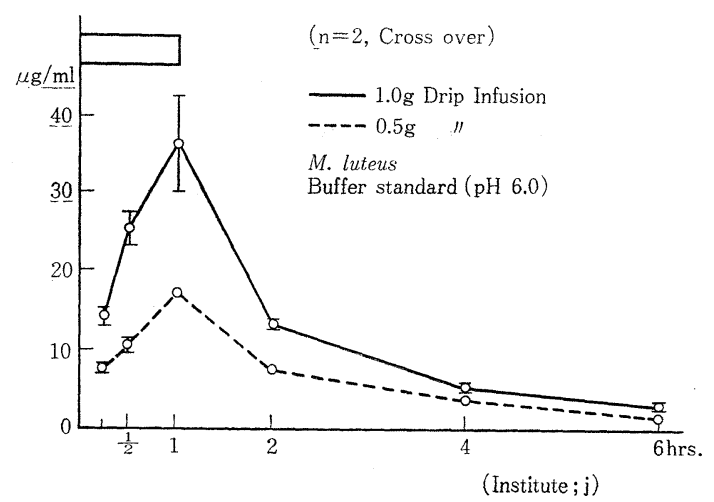


Fig. 12 Serum Levels and Urinary Recovery in Multiple Administration

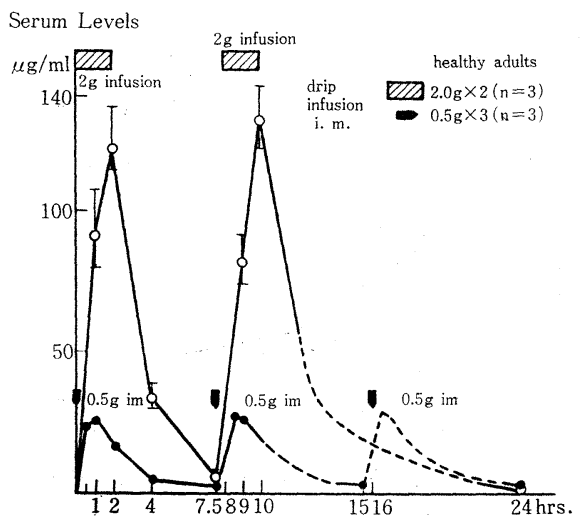

Urinary Recovery

\begin{tabular}{|l|c|c|c|}
\hline & $0 \sim 8 \mathrm{hr}$ & $8 \sim 16 \mathrm{hr}$ & $16 \sim 24 \mathrm{hr}$ \\
\hline $\begin{array}{l}\text { i. } \mathrm{m} . \\
0.5 \mathrm{~g} \times 3\end{array}$ & $83.5 \pm 6.4$ & $85 \mathrm{~g}$ & $0.5 \mathrm{~g}$ \\
\cline { 2 - 4 } & $8.5 \mathrm{~g}$ & 85.5 & $89.4 \pm 5.1$ \\
\hline $\begin{array}{l}\text { drip } \\
\text { infusion } \\
2.0 \mathrm{~g} \times 2\end{array}$ & $92.3 \pm 1.9$ & \multicolumn{3}{|c|}{$94.6 \pm 0.9$} \\
\cline { 2 - 4 } & $2 \mathrm{gg} \lambda$ & $22 \mathrm{~g} \lambda$ & \\
\hline
\end{tabular}

(Institute ; c)

つぎに cross over 法による血中濃度の dose response についての検討では, 筋注については Fig. 9 のように $500 \mathrm{mg}$ と $250 \mathrm{mg}$ の間に，はつきりとし た dose response が認められている. また one shot 静注における1g と $500 \mathrm{mg}$ (Fig。10), 点滴静注 に持ける $1 \mathrm{~g}$ と500mg (Fig. 11)でも同様に，はつ きりとした dose response が認められている。

連続投与時の 血中濃度については，Fig. 12の ように $2 \mathrm{~g}$ を 8 時間間隔で 2 回点滴静注した場合 と，500mg を 8 時間間隔で 3 回筋注した場合に ついて検討されているが，いずれも血中に蓄積す る傾向は全く認められず，また尿中回収率にも変 化は認められていない。

これらの血中濃度を cefazolin (CEZ) と比較 した成績では，Fig.130ように標準液系列の希 釈にヒト血清を用いた場合は CEZ に比し全般に 低く，また half life も若干短くなつているが， buffer 希勫の成績では peak 時前後の血中濃度が 逆転している点が興味深い。

腎機能障害患者に和子る 血中濃度は，Fig. 14 のように $1 \mathrm{~g}$, one shot 静注, $1 \mathrm{~g}$ 点滴静注のいず
Fig. 13 Comparison of Serum Levels of Cefmetazole to CEZ

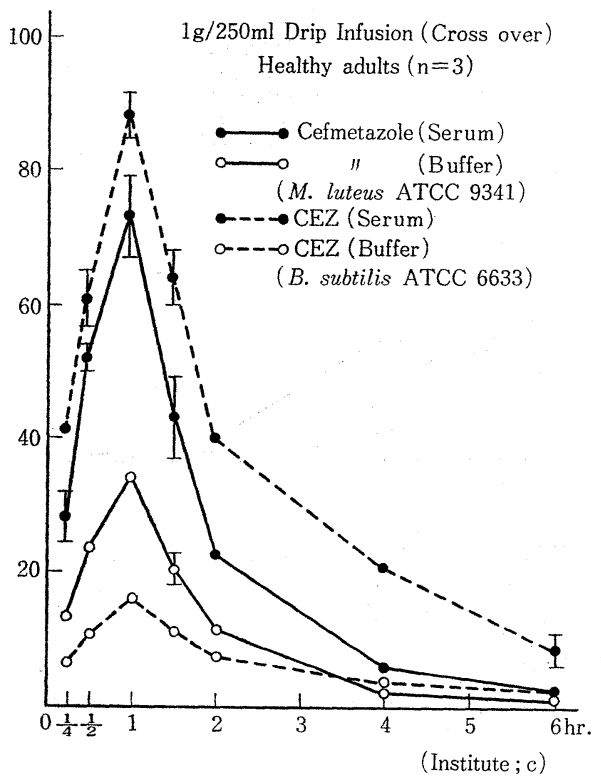

Fig. 14 Serum Levels of Cefmetazole in Patients with Renal Impairment

1) $1 \mathrm{~g}$ Intravenous Injection

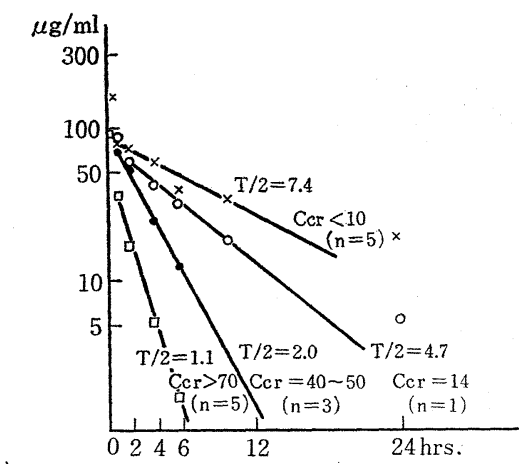

2) $1 g$

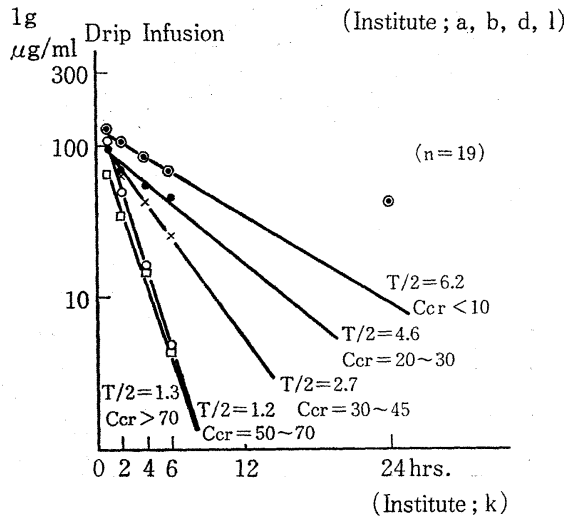


Fig. 15 Urinary Excretion of Cefmetazole

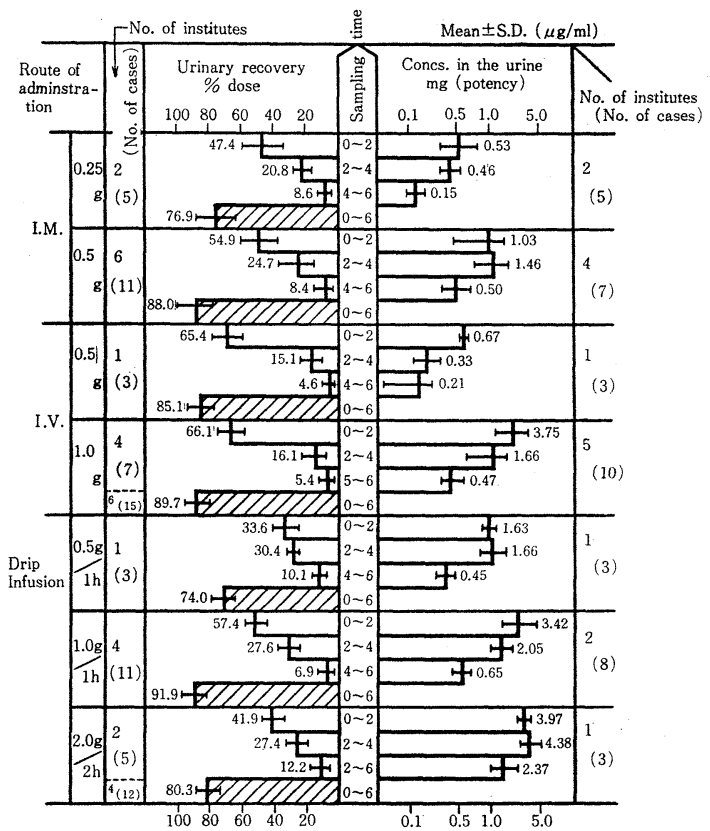

Fig. 16 Comparison of Urinary Excretion of $\mathrm{Ce}-$ fmetazole to $\mathrm{CEZ}$

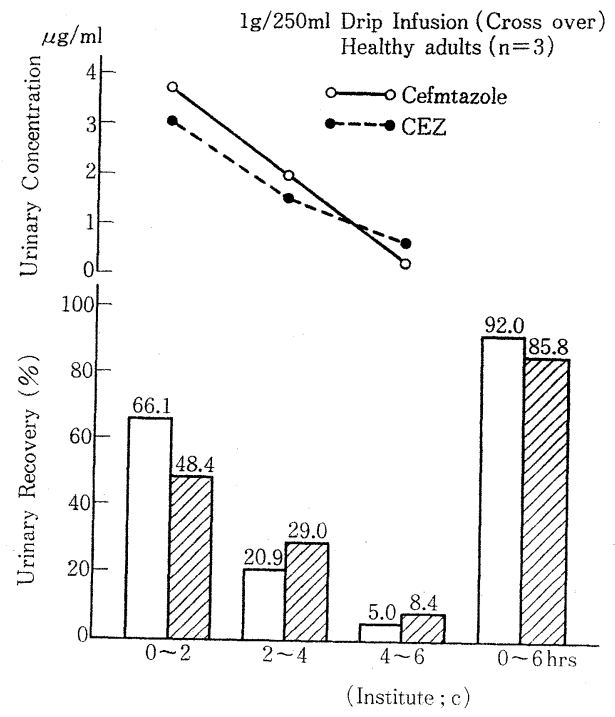

れの場合に括いても， Ccr が70 ml/min 以上あれ ば，それ程大きな影響は受けないようであるが， $70 \mathrm{ml} / \mathrm{min}$ 以下になると，障害の程度に応じて血 中濃度は高く，かつ遷延する傾向を示し， half
Fis. 17 Urinary Excretion of Cefmetazole in $\mathrm{Pa}$ tients with Renal Impairment

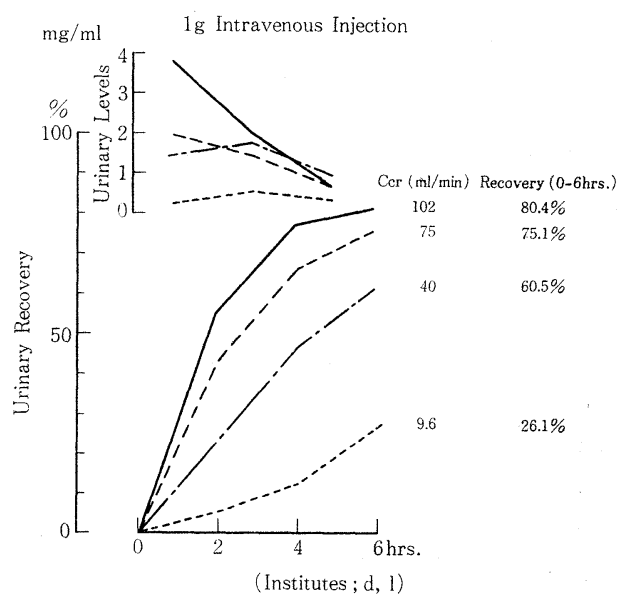

life も延長している.

3. 尿中和よび胆汁中排泄

各種の投与法，投与量に和汁るCefmetazole の 尿中濃度扰よび尿中回収率を，一括して Fig. 15 に示した. 本剂は筋注, one shot 静注, 点滴静注 のいずれに拉いてもさわめて高い尿中濃度が得ら れ，また尿中への移行はすみやかであり，6時間 までの尿中回収率は74～92\% と高率であつた。

これを cross over 法により CEZ と比較した場 合，1g 点滴静注では Fig. 160ように， 0〜2 時間の尿中濃度，尿中回収率は本剂の活らが高 く，6時間までの尿中回収率でも本剤の汪らが若 干高い傾向を示している。

腎機能障害患者に护活る尿中排泄は，Fig. 17 のように障害の程度に応じて尿中濃度は低く, ま た尿中回収率名低下している。

胆汁中濃度が測定された症例は11例あり，これ を一括して Table 3 に示した. 胆汁中濃度の peak は $3.2 \mu \mathrm{g} / \mathrm{ml}$ から $224 \mu \mathrm{g} / \mathrm{ml}$ まで，また回収率は $0.08 \%$ か $1.99 \%$ をでと, 症例によりかなりのば らつきが見られている。これはもらろん，投与量 や投与経路のちがいにもよろらが，肝障害の程度 や胆道閉塞の程度などによつて大さく影響された ものと考光られ，他のセファロスポリン系薬剤と 比較した場合，大差のない成績と思われる。 
Table 3 Biliary Levels of Cefmetazol

\begin{tabular}{|c|c|c|c|c|c|c|c|c|c|c|c|c|c|c|c|c|c|c|c|c|c|c|}
\hline \multirow[b]{2}{*}{ Dose } & \multirow[b]{2}{*}{ 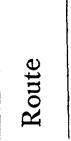 } & \multirow[b]{2}{*}{ 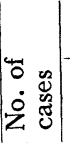 } & \multicolumn{9}{|c|}{ Biliary level $(\mu \mathrm{g} / \mathrm{ml})$} & \multirow{2}{*}{ 窟 } & \multicolumn{8}{|c|}{ Blood level $(\mu \mathrm{g} / \mathrm{ml})$} & \multirow{2}{*}{ 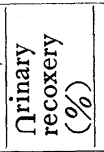 } & \multirow{2}{*}{ 旁 } \\
\hline & & & 1 & 2 & 3 & 4 & 5 & 6 & 7 & 8 & 24 & & 30 分 & 1 & 2 & 2 & 4 & 5 & 6 & $\begin{array}{c}8 \\
\mathrm{hrs}\end{array}$ & & \\
\hline $0.5 \mathrm{~g}$ & i.m. & 1 & 14 & 83.5 & 1198 & 37.55 & 52.5 & 9.5 & & & & 1.99 & 23.12 & 21.8 & 16.1 & & 5.9 & & & & & \multirow{2}{*}{$\mathrm{g}$} \\
\hline $0.5 \mathrm{~g}$ & i.m. & 1 & & 9.6 & 8.0 & 4.1 & 6.6 & 4.7 & & & & 0.12 & 22.3 & 27.5 & 19.3 & & 6.0 & & & & & \\
\hline $1.0 \mathrm{~g}$ & i.v. & 1 & & 74 & & & & & & & & & & 53 & 33.7 & 14.4 & & & & & & $\mathrm{~m}$ \\
\hline $1.0 \mathrm{~g}$ & i.v. & 1 & & 26.2 & 165 & 224 & 117 & 49 & & & 9.9 & 0.34 & 128 & 100 & 65 & 46 & 20.6 & 10.5 & 6.6 & & & f \\
\hline $1.0 \mathrm{~g}$ & * & 1 & 0 & 6.6 & 6.6 & 3.7 & 1.6 & 1.1 & & & & 0.1 & 78 & 84 & 44 & & 14 & & 8.1 & & 91 & f \\
\hline $1.0 \mathrm{~g}$ & * & 1 & 1 & 6 & 20 & 12 & 6 & 3.5 & 3.5 & 2 & & 0.08 & & & & & & & & & & $\mathrm{~h}$ \\
\hline $1.0 \mathrm{~g}$ & $*$ & 2 & 23.7 & 8.9 & & 2.6 & & & & 0.9 & & & & & & & & & & & & \multirow{4}{*}{0} \\
\hline $1.0 \mathrm{~g}$ & $*$ & 2 & 2.8 & 3.2 & & 1.0 & & & & 1.7 & & & & 81 & 38 & & 5.6 & & & 1.2 & & \\
\hline $2.0 \mathrm{~g}$ & $*$ & 1 & 35.5 & 19.2 & & 4.6 & & & & 0.6 & & & & 80 & 47.5 & & 17.2 & & & 3.2 & & \\
\hline $2.0 \mathrm{~g}$ & $*$ & 1 & - & - & & 0.7 & & & & - & & & & 63 & 26.8 & & 6.0 & & & & & \\
\hline $2.0 \mathrm{~g}$ & i.v. & 1 & & 14.9 & & 19.7 & & 7.1 & & & & 0.20 & & & & & & & & & 91 & c \\
\hline
\end{tabular}

* infusion

Fig. 18 Tissue Concentrations of Cefmetazole in Mice

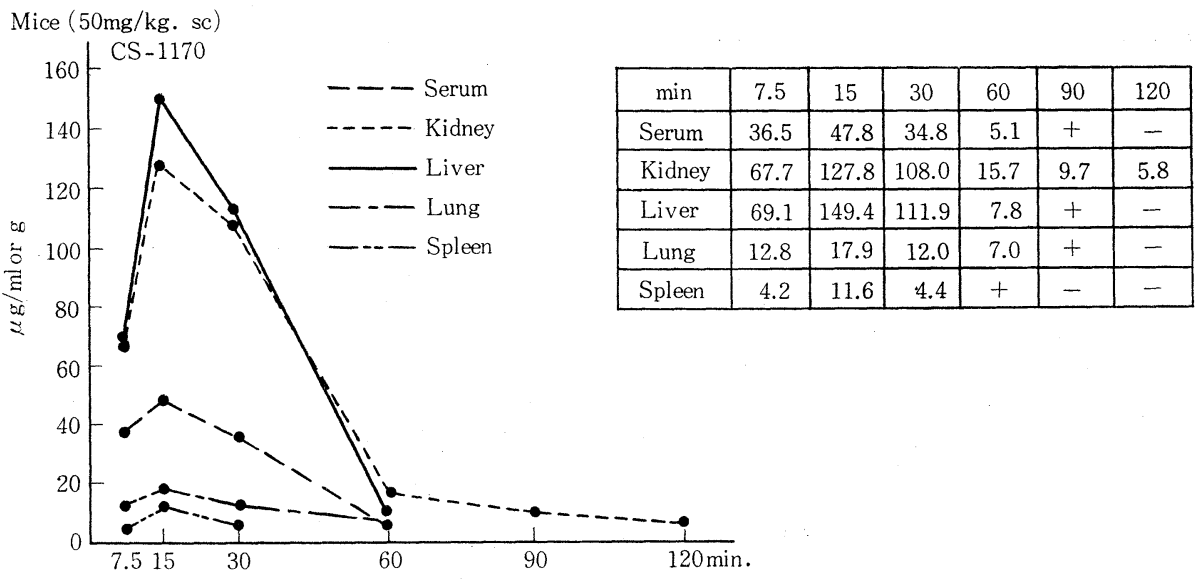

4. 喀痰中および組織内濃度

本剂 $1 \mathrm{~g}$ 点滴静注後の喀痰中濃度の peak は, $4 \sim 6$ 時間後に見られ，2〜 $4 \mu \mathrm{g} / \mathrm{ml}$ の濃度が得ら れて沶り， cross over 法により測定された CEZ の喀痰中濃度より若干高い傾向を示している。

このほか手術時の摘出標本について測定された ヒト組織内濃度として, 腎, 前立腺, 包皮, 睪丸 などについても検討が行われている。これらの測 定值は症例もすくなく，投与量，投与後の時間が 必ずしも一定しておらず，また腎組織内濃度など では，腎機能の障害程度によつても影響を受ける
と考えられるので一概には言えないが，腎では平 均して, 同時刻に新子る血中濃度の 3 倍程度, 前 立腺では同じく20\%前後の濃度が得られている。 また脐带血清濃度, 羊水移行などについても検討 されているが，他のセファロスポリン系薬蝺と大 差はないよらに思われる。

5. 動物に和㺭る体内分布

動物に打ける体内分布としては，マウス，ラッ ト，サル，イヌ，ウサギなどについて，血中，尿 中, 胆汁中濃度をはじめ, 糞便中回収率, リンパ 液中濃度, 各種臓器内濃度などについて検討され 
Table 4 Biliary Concentration and Excretion Rate of Cefmetazole in Animals

(Dose $50 \mathrm{mg} / \mathrm{kg}$ )

\begin{tabular}{c|c|c|c|c}
\hline \multirow{2}{*}{ Animal } & \multicolumn{2}{|c|}{ Cefmetazole } & \multicolumn{2}{c}{ CEZ } \\
\cline { 2 - 5 } & $\begin{array}{c}\text { Excretion Rate } \\
(\%)\end{array}$ & $\begin{array}{c}\text { Max. Conc. } \\
(\mu \mathrm{g} / \mathrm{ml})\end{array}$ & $\begin{array}{c}\text { Excretion Rate } \\
(\%)\end{array}$ & $\begin{array}{c}\text { Max. Conc. } \\
(\mu \mathrm{g} / \mathrm{ml})\end{array}$ \\
\hline $\operatorname{rat}(\mathrm{sc})$ & $58.02 \pm 6.52$ & $4150.0 \pm 180.3$ & $24.82 \pm 2.55$ & $2836.0 \pm 472.6$ \\
\hline $\operatorname{dog}(\mathrm{im})$ & $14.63 \pm 1.56$ & $3383.3 \pm 651.8$ & $3.82 \pm 1.78$ & $2289.2 \pm 1291.2$ \\
\hline rabbit $(\mathrm{im})$ & $1.35 \pm 0.31$ & $183.8 \pm 67.9$ & $0.28 \pm 0.03$ & $18.3 \pm 3.4$ \\
\hline
\end{tabular}

$0 \sim 24$ hrs.

Fig. 19 Tissue Concentrations of Cefmetazole in Rats

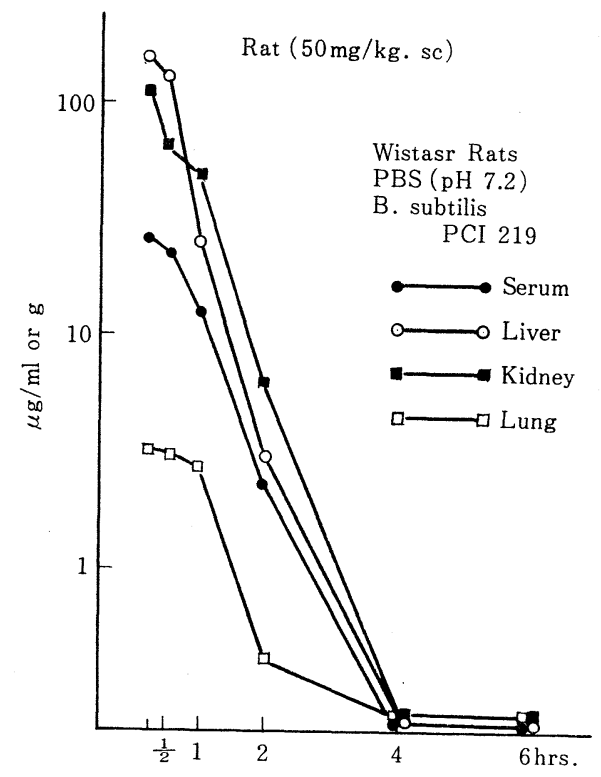

ているが，ここでは臓器内濃度を中心にして述べ る.

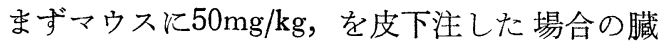
器濃度は, Fig. 18のよらに肝に最も高く, つい で腎, 血清, 肺, 脾の順となつているが，これは同 量の CEZ を投与した場合にくらべ，腎では若干 低く，肝では若干高い傾向を示している。また同 量の cephalothin (CET) を投与した場合にくら ベると，いずれの臓器においても著るしく高い濃 度となつている。

またラットに $50 \mathrm{mg} / \mathrm{kg}$ を皮下注した場合の臓 器内濃度は, Fig. 190ようにマウスとほぼ同様
の傾向を示して括り，本剤がとくに肝，腎への移 行がよいことを示している.

この浪か胆汁中排泄では Table 4 のように，動 物の種類によりかなり差のあることが特徴的であ り，24時間までの総排泄率は，ラットでは58\%と きわめて高いが，ウサギでは $1.35 \%$ と低く，これ を反映して粪便中排泄率も，ラットでは48時間ま でに37.5\%と高いがウサギでは0.23\%と低くなつ ている。

\section{6. 代謝}

代謝物については，ラット，ヒトの㽷和よびサ ルの血液などについて, TLC スキャン, バイオ オートグラフィー， TLC オートラジオグラフィ 一などを用いて検討されているが，いずれも代謝 物は検出されていない。

\section{III. まとめ}

Cefmetazole の吸収, 排泄, 分布, 代謝などに 関して, 全国32の研究機関からの成績を集計し た。

本剂は筋注, one shot 静注，または点滴静注に よりすみやかに血中に移行し, 高い血中濃度に 達するが, 血中からの消失は CEZ よりは速く, CET よりは緩徐であり，その中間にあると考え られた。

また尿中への排泄は良好であり，体内では代謝 を受けず，大部分が短時間内に活性型のまま尿中 に排泄されるものと考觉られた。

（本論文の要旨は，昭和52年12月，第25回日本化学療 法学会西日本支部総会, 新薬シンポジウムII CS-1170 K おいて発表した。) 
Report II. Absorption, Excretion, Distribution and Metabolism

\section{Yukimichi KAWADA \\ Department of Urology, Gifu University School of Medicine}

The results of studies in 32 research institutes in Japan regarding absorption, excretion, distribution and metabolism of cefmetazole are summarized as follows:

After intramuscular injection, one-shot intravenous injection or intravenous drip infusion, cefmetazole is rapidly absorbed and transferred into blood resulting in high blood concentrations and its disappearance from blood is faster than CEZ but slower than CET, somewhere in between these two drugs in the blood concentration half life.

Excretion of cefmetazole into urine is favorable, indicating that it is not metabolized in vivo and the major portion is excreted in urine in unchanged active form. 